\title{
Resolving Serological Blood Group Discrepancy and Providing Transfusion Support in a Patient of Mixed Auto Immune Hemolytic Anemia: A Case Report
}

\author{
Debasish M1, Dibyajyoti S1*, Gopal KR² and Rashmita P2 \\ ${ }^{1}$ Department of Transfusion Medicine, All India Institute of Medical Sciences, India \\ ${ }^{2}$ Department of Transfusion Medicine, SCB Medical College, India
}

*Corresponding author: Dibyajyoti Sahoo, Department of Transfusion Medicine, All

\section{Case Report}

Volume 2 Issue 1

Received Date: March 22, 2018

Published Date: April 02, 2018

DOI: $10.23880 / \mathrm{hij}-16000118$ India Institute of Medical Sciences, Bhubaneswar, ODISHA 751019, India, Email: dib.jit@gmail.com

\section{Abstract}

ABO grouping should include both forward and reverse grouping procedure, and results of two procedures should agree with each other. Mixed autoimmune hemolytic anemia (AIHA) is defined as presence of both warm and cold autoantibodies. Approximately $20 \%$ of AIHA are associated with cold-reactive antibodies. Warm autoantiboies are responsible for $48-70 \%$ of AIHA cases. About half of patients are termed idiopathic without any underlying causes. Secondary cases are associated with underlying diseases or with certain drugs. Diagnosis is based on detection of autoantibodies by monospecific Direct antiglobulin test (DAT) showing positive reaction on IgG and Complement C3d and presence of cold agglutinins. We report a case of mixed AIHA in $35 \mathrm{yr}$ old lady who had severe anemia, blood group discrepancy, crossmatch incompatibility. We provided 2 units of Best matched blood (least incompatible) and she responded to corticosteroids. To our knowledge a careful communication between the transfusion services and clinicians can avoid unnecessary blood transfusions in such cases especially in clinically responding patients.

Keywords: Blood Group Discrepancy; Autoimmune Hemolytic Anemia (AIHA); Direct Antiglobulin Test (DAT); Least incompatible Blood

Abbreviations: AIHA: Autoimmune Hemolytic Anemia; DAT: Direct Antiglobulin Test; CTT Conventional Tube Technique; PEG: Polyethelene Glycol; SLE: Systemic Lupus Erythematosis; CAD: Cold Agglutinin Disease

\section{Introduction}

ABO blood group system, initially described by Karl Landsteiner in 1900, is the most important blood group system in transfusion and organ transplantation medicine [1]. This system consists of four antigens - $A, B$ $\mathrm{AB}$ and $\mathrm{A} 1$, and Four phenotypes- $\mathrm{A}, \mathrm{B}, \mathrm{AB}$, and 0 blood groups. A feature of the $A B O$ system is the regular occurrence of Anti-A and Anti-B in the absence of the corresponding red cell antigens Thus, the individuals with blood group $\mathrm{A}$ possesses $\mathrm{A}$ and $\mathrm{H}$ antigens on their red blood cells and demonstrate Anti-B in the serum, the individuals with blood group $\mathrm{B}$ possesses $\mathrm{B}$ and $\mathrm{H}$ 
antigens on red blood cells and demonstrate Anti-A in the serum, in blood group $\mathrm{O}$ there is only $\mathrm{H}$ antigen on red cells along with Anti-A and Anti-B in the serum, and finally in persons with blood group $A B$ there are $A, B$ and $\mathrm{H}$ antigens on red cells with no antibody (Anti-A and Anti-B) in the serum.ABO grouping consists of testing the red cells with Anti-A and Anti-B reagents for determining the antigens on red cells (Forward) and testing the serum for expected antibodies by using $\mathrm{A} 1$ and $\mathrm{B}$ red cells (Reverse). ABO grouping should include both forward and reverse procedures, and the results of the two methods should agree with each other [2]. An ABO discrepancy implies that the forward, $\mathrm{ABO}$ grouping does not agree with the reverse, $\mathrm{ABO}$ grouping. In patients, an $\mathrm{ABO}$ discrepancy must be resolved before transfusion of any blood components, and in donors, the discrepancy must be resolved before any blood is labelled with a blood type [3].

Autoimmune haemolytic anemia (AIHA) consists of a group of acquired haemolytic anemias which result from the development of auto antibodies directed against antigens on the surface of patient's own red blood cells [4]. AIHA is classified into warm and cold antibody types. Warm antibody AIHA belong to IgG class, react at temperatures $37^{\circ} \mathrm{C}$, do not require complement for activity and do not produce agglutination invitro. On the other hand cold antibodies are of IgM class which react at temperatures $0-4^{0} \mathrm{C}$, require complement for activity and produce spontaneous agglutination of red blood cells in vitro [5]. Mixed warm and cold antibody AIHA is the presence of both warm and cold autoantibodies [6]. We report a case of mixed AIHA who presented with severe anemia with blood group discrepancy.

\section{Case Report}

A 35-year-old female was referred to our hospital with complaints of jaundice, weakness and breathlessness. On general physical examination, there was marked pallor, icterus, tachycardia and tachypnea. Hematological investigations revealed severe anemia $(\mathrm{Hb}-3.8 \mathrm{gm} / \mathrm{dl})$, leucopenia (TLC-3,300). Peripheral smear shows anisocytosis, poikilocytosis, polychromacia. Liver function tests were deranged with indirect hyperbilirubinemia $(2.67 \mathrm{mg} / \mathrm{dl})$. Serum LDH $927 \mathrm{pg} / \mathrm{ml}$, MCV 117 fl, MCH 28, MCHC 32. Patient had adequate urine output. The patient's sample was received in the blood bank for crossmatching. Cell and serum grouping showed a discrepancy with strong positive auto-control. Patient was typed as $0 \mathrm{Rh}-\mathrm{D}$ positive with autoantibodies. Direct antiglobulin test with poly-specific Coomb's reagent (IgG + C3d) (Ortho diagnostics) was positive. Patient also had a positive antibody screen with all three reagent cells in the anti-human globulin test (Ortho cell panel, Ortho Diagnostics).

\section{Immunohematological Work-Up}

Both EDTA and plain samples were asked, showed tinge of haemolysis with visible spontaneous agglutinates. Her blood grouping by CTT (Conventional Tube Technique) showed discrepancy, where forward grouping suggested to be $\mathrm{AB} R \mathrm{Rh}$ positive while the reverse grouping showed varying grades of agglutination with in-house prepared A1, B and O pooled cells (Table 1 ). The discrepancy was resolved by repeating forward grouping after washing the red cells six times with warm saline and reverse grouping done after incubation at $37^{\circ} \mathrm{C}$ for $1 \mathrm{hr}$ (Table 2 ).

\begin{tabular}{|c|c|}
\hline Reagent & Grade of reaction \\
\hline Anti-A & $2+$ \\
\hline Anti-B & $2+$ \\
\hline Anti-D & $4+$ \\
\hline Autocontrol & $4+$ \\
\hline A1 cell & $4+$ \\
\hline B cell & $4+$ \\
\hline O cell & $2+$ \\
\hline Interpretation & ? Cold Autoantibody \\
\hline
\end{tabular}

Table 1: Initial blood grouping showing discrepancy.

\begin{tabular}{|c|c|}
\hline Reagent & Grade of reaction \\
\hline Anti-A & 0 \\
\hline Anti-B & 0 \\
\hline Anti-D & $4+$ \\
\hline A1 cell & $4+$ \\
\hline B cell & $4+$ \\
\hline O cell & 0 \\
\hline Interpretation & 0 RhD Positive \\
\hline
\end{tabular}

Table 2: Repeat Blood Grouping after prewarming technique.

\section{Further Immuno-Hematological Tests}

Patient's EDTA blood sample shows visible agglutinates on naked eye while performing direct antiglobulin test (DAT). In order to resolve we asked fresh sample and kept at $37^{\circ} \mathrm{C}$ (pre-warmed) and $1 \mathrm{ml}$ of packed red cell washed six times with prewarmed saline. DAT (polyspecific) shows 4+ reaction. On monospecific DAT shows IgG $(3+)$ and C3d (3+). Antibody screening with Glass-bead CAT technology (Ortho diagnostic) showed pan-agglutination (4+) (Table 3). Antibody 
identification by 11 cell panel also showed panagglutination $(4+)$.

\begin{tabular}{|c|c|c|c|c|c|c|c|}
\hline Screening cell & Panel & Panel & Panel & \multicolumn{4}{|c|}{ Auto control } \\
\cline { 5 - 8 } & II & III & $4^{\circ} \mathrm{C}$ & $22^{\circ} \mathrm{C}$ & $37^{\circ} \mathrm{C}$ & $\begin{array}{c}\text { AHG } \\
\text { phase }\end{array}$ \\
\hline $\begin{array}{c}\text { Strength of } \\
\text { Agglutination }\end{array}$ & $4+$ & $4+$ & $4+$ & $4+$ & $4+$ & $4+$ & $4+$ \\
\hline
\end{tabular}

Table 3: Antibody screening results for the patients.

\section{Elution}

To confirm result of DAT positive due to autoantibody (IgG) Cold-acid elution (Glycin-HCL in house prepared) performed on DAT positive RBCs after six times washing with normal saline. The subsequent eluate recovered after elution was incubated with screening panel cell (Ortho diagnostic) shows Pan-agglutination (4+) (Figure 1). Supernatant of last red cell wash was taken as control, which showed negative implying test to be valid. Elution is particularly important if the patient had received a transfusion in the recent past and the DAT result is not very strong or if mixed field agglutination is noted when the cells are inspected microscopically. Such findings point to an alloantibody bound to the still circulating transfused RBCs instead of an autoantibody attached to the patient's own cells. In cases of a positive DAT result owing to an alloantibody, the eluate should react only with selected reagent cells containing the antigen recognized by the antibody.

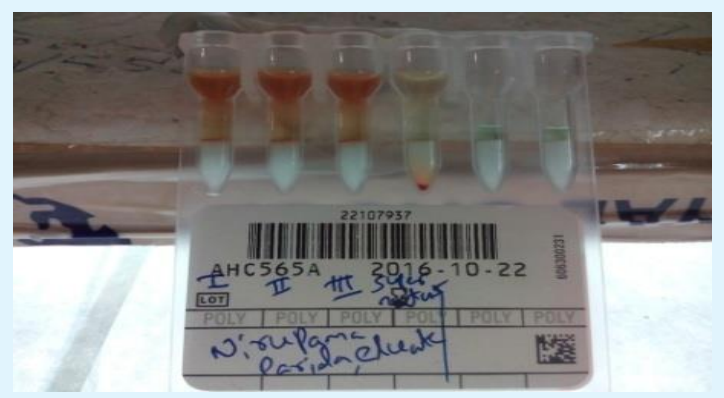

Figure 1: Cold-Acid elution result shows panagglutination.

\section{Adsorption}

A serum sample containing a warm autoantibody that reacts with the full panel needs to be evaluated further for the concomitant presence of RBC alloantibodies. Adsorption is especially important for patients with a history of pregnancy or transfusion and in patients whose history is unknown and transfusion is likely. Auto adsorption done using patients own RBCs. but patient should not be transfused within 3 months and should not be severe anemic. Alloadsorption done with allogenic red cells in patient who transfused in last 3 months and hemoglobin is less than $7 \mathrm{gm} \%$. Allogenic adsorption was done using PEG (polyethelene glycol) with panel cell (containing all clinical significant red cell antigens) after incubation at $37^{\circ} \mathrm{C}$ for $15 \mathrm{~min}$. After adsorption, adsorbed serum tested with panel cell shows no reaction hence alloantibody ruled out (Table 4). In this case both cold and warm autoantibody present with absence of clinically significant alloantibodies.

\begin{tabular}{|c|c|c|c|}
\hline $\begin{array}{c}\text { Screening cell on adsorbed } \\
\text { serum }\end{array}$ & $\begin{array}{c}\text { Panel } \\
\text { Cell I }\end{array}$ & $\begin{array}{c}\text { Panel } \\
\text { cell II }\end{array}$ & $\begin{array}{c}\text { Panel } \\
\text { cell III }\end{array}$ \\
\hline Strength of agglutination & 0 & 0 & 0 \\
\hline
\end{tabular}

Table 4: PEG Adsoption using Allogenic Adsoption results.

Since the patient already transfused 2 units of whole blood, detailed phenotyping could not be done. As no alloantibodies were there and no compatible unit was found, we went for best matched blood. Crossmatching was performed with several random $\mathrm{O} R \mathrm{Rh}$ positive packed red cells, she received three 'least incompatible' 0 $\mathrm{Rh} \mathrm{D}$ positive packed red cell units over three days as a life-saving measure after informed consent. Best match (least incompatible) blood given as tested cross match strength less than autocontrol strength (Figure 2). No adverse events were reported during or after transfusion. She was also started on steroid therapy (Inj Methyl prednisolone $1200 \mathrm{mg}$ per day for 3 days followed by oral prednisolone) with other supportive therapy. Her condition gradually improved.

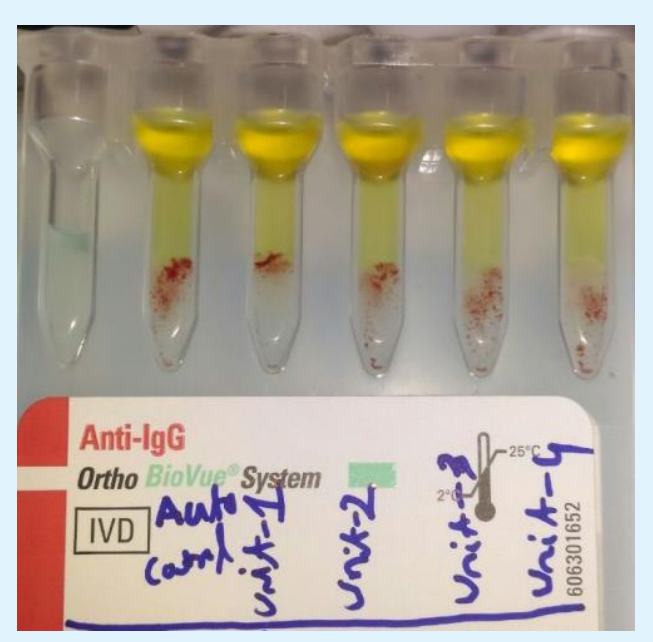

Figure 2: Best match blood transfusion based on reaction strength with autocontrol. 


\section{Discussion}

Autoimmune haemolytic anemia is an uncommon disorder with incidence 1-3 cases per 100000 per year. $[7,8]$ Warm autoantiboies are responsible for $48-70 \%$ of AIHA cases $[9,10]$. Diagnosis of AIHA is based on evidence of haemolytic anemia consisting of anemia, jaundice, splenomegaly, reticulocytosis, raised serum bilirubin and a positive DAT [4]. Once AIHA has been identified, differentiation between warm and cold antibodies can be done by monospecific DAT which also identifies responsible mechanisms. If the reaction is positive with anti IgG and negative with anti $\mathrm{C} 3 \mathrm{~d}$, it is usually due to warm antibodies which are common in idiopathic or drug associated AIHA. If the reaction is positive with both anti IgG and anti C3d, it also indicates warm autoantibodies and is more common in patients with mixed AIHA, systemic lupus erythematosis (SLE) and Idiopathic AIHA. In cold agglutinin disease (CAD), the reaction is positive with anti $\mathrm{C} 3 \mathrm{~d}$ but negative with anti IgG [11]. There may be presence of agglutination of red cells at temperatures 37C in cold type of AIHA [5]. In the present case, initially a misdiagnosis of cold antibody AIHA was made based on positive polyspecific DAT, red cells agglutination at room temperature which reversed on warming the slide and presence of cold agglutinins at $4^{\circ} \mathrm{C}$. However, monospecific DAT done subsequently was positive for anti IgG and anti C3d indicating warm antibodies. So we revised our diagnosis as a mixed type of AIHA thereby emphasising the importance of monospecific DAT.

Clinical management of patients with hemolytic anemia varies according to the causative disease state. All patients with hemolytic anemia, especially those with chronic hemolysis, will have increased requirements for folate and need to be supplemented with oral preparations continuously. Corticosteroids generally are the first line of therapy. Patients unresponsive to corticosteroids or those without sustained remission are candidates for combined chemotherapy and/or splenectomy. Our Patient was managed with steroid, haematinics \& PRBCs. Her initial hematocrit had reached as low $12 \%$ but then gradually improved during course of her hospital management. At time of discharge from hospital her hematocrit reached 30\% and her general condition improved. Currently patient is being followed as an outpatient.

\section{Conclusion}

To our knowledge good communication between clinicians and transfusion services required to avoid unnecessary transfusion, transfusion given when required. The final decision to transfuse should depend on evaluation of patient's clinical status and the benefits must be weighted to the potential risks of transfusion.

\section{References}

1. Watkins WM (2001) The ABO blood group system: Historical background. Transfus Med 11(4): 243-265.

2. Makroo RN (1999) ABO Blood group system. Compendium of Transfusion Medicine. $1^{\text {st }}$ (Edn.), New Delhi, Alps Printers pp: 28-32.

3. Denise MH, Deborah F (1998) ABO blood groups, Modern Blood Banking and Transfusion Practices. $3^{\text {rd }}$ (Edn.), New Delhi, Jaypee Brothers Medical publishers (p) Ltd pp: 89-101.

4. De Gruchy GC (1989) The haemolytic anaemias. In: Firkin FC, et al. (Eds.), De Gruchy'sclinical haematology in medical practice, $5^{\text {th }}$ (Edn.), BlackwellScience Ltd., Edinburgh, pp: 172-215.

5. Segel GB (2007) Hemolytic anemias resulting from extracellularfactors. In: Behrman RE, et al. (Eds.), Nelson textbook of pediatrics, $18^{\text {th }}$ (Edn.), Saunders, Philadelphia, pp: 2042-2044.

6. Culic S, Kuljis D, Ivankovic Z, Martinic R, Maglic P, et al. (1999) Various triggers for autoimmune haemolytic anemia in childhood. Paediatr Croat 43: 207-210.

7. Pirofsky B (1969) Auto immunization and the auto immune haemolytic anaemias. Baltimore: Williams and Wilkins.

8. Bottiger LE, Westerholm B (1973) Acquired haemolytic anaemia. Incidence and aetiology. Acta Med Scand 193(1-6): 223-226.

9. Sokol RJ, Hewitt S, Stamps BK (1981) Autoimmune hemolysis: an 18 year study of 865 cases referred to a regional transfusion centre. Br Med J 282(6281): 2023-2027.

10. Petz LD, Garraty G (1980) Acquired immune hemolytic anemias. New York: Churchill Livingstone.

11. Lichtin AE (2009) Autoimmune haemolytic anemia. 


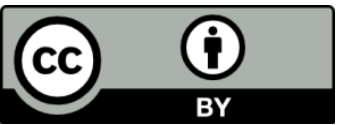

